\title{
Maturation of caffeine elimination in infancy
}

\author{
JACOB V. ARANDA, JUDITH M. COLLINGE, RAEZELLE ZINMAN, AND \\ GORDON WATTERS
}

\begin{abstract}
Departments of Newborn Medicine and Neurology, McGill University-Montreal Children's Hospital Research Institute, and Roche Developmental Pharmacology Unit, Department of Pharmacology and Therapeutics, McGill University, Montreal
\end{abstract}

SUMMARY The developmental changes in caffeine elimination were studied in 7 infants aged between $2 \frac{1}{2}$ weeks and 6 months. Adult plasma clearance rate of caffeine was achieved at 3 to $4 \frac{1}{2}$ months of age. Plasma half-life and elimination rate reached adult levels after 3 to $4 \frac{1}{2}$ months and seemed to exceed adult capacity thereafter. No significant changes in apparent volume of distribution were noted. Our data provide some indication of the age in infancy when the low rates of caffeine elimination in the neonate increase to the adult rate.

Caffeine $(1,3,7$, trimethylxanthine) is a central nervous system stimulant with many pharmacological activities. It is an ubiquitous compound found in many beverages, food, and medicines. Substantial exposure of the developing human organism to this compound occurs via placental transfer (Parsons et al., 1976; Bory et al., 1979) postnatally via breast milk (Horning, 1977) or intentionally in the treatment of neonatal apnoea (Aranda et al., 1977a). The elimination of this drug in the human neonate is exceedingly slow, far more so than is the case with other drugs (Aranda et al., 1977b, 1979). The plasma half-life and clearance in the premature neonate ranges from 40 to 230 hours $($ mean $=100)$ and 2.5 to $16.8 \mathrm{ml} / \mathrm{kg}$ per $\mathrm{h}$ (mean $=8 \cdot 9$ ), respectively. This implies that the breast-fed newborn and young infant with a significant daily intake of caffeine via maternal breast milk could potentially accumulate caffeine in the body. However, beyond the neonatal period, there are no data on the elimination of caffeine, and the present study therefore attempts to define how caffeine elimination changes in early infancy. The investigative use of caffeine for the prevention of 'cot death' has afforded the opportunity to perform these studies.

\section{Materials and methods}

A total of 10 doses of caffeine citrate, 8 as single IV

Department of Paediatrics, Montreal Children's Hospital, Canada

JACOB V. ARANDA, associate professor of paediatrics, pharmacology, and therapeutics

JUDITH M. COLLINGE, neonatal research nurse

RAEZELLE ZINMAN, lecturer in paediatrics

GORDON WATTERS, professor of paediatrics and neurology infusions and 2 as single oral doses, were given to 7 infants whose ages ranged from $2 \frac{1}{2}$ weeks to 6 months. Five infants were admitted for investigation of 'near-miss' sudden infant death syndrome. An additional 2 sick infants with severe apnoea were also included. One 3-month-old infant had complex congenital heart disease, congestive heart failure, and apnoea, and was respirator dependent. One 6-month-old infant had persistent apnoea with Arnold-Chiari malformation. One infant with 'near-miss' sudden infant death syndrome was studied at ages $2 \frac{1}{2}, 5$, and 10 weeks. Another infant was also studied sequentially at ages $4 \frac{1}{2}$ and 5 months. Informed consent was obtained from the parents. This study protocol was approved by the Scientific Review Committee and the Ethics Committee of the Montreal Children's Hospital.

After the IV or oral administration of caffeine citrate $(10 \mathrm{mg} / \mathrm{kg}$ of caffeine base), multiple capillary blood samples were obtained at varying intervals from 30 minutes to 72 hours. Using a plasma volume of $10 \mu \mathrm{l}$, caffeine was measured by radioimmunoassay as described by Cook et al. (1976). Metabolite cross-reactivity is negligible as previously determined at this laboratory.

Data were analysed using a one-compartment model. This analysis has been shown to be applicable in the pharmacokinetic disposition of caffeine in the newborn (Aranda et al, 1979), and of theophylline in the newborn (Aranda et al., 1976) and young infant (Loughnan et al., 1976). The plasma concentrations of caffeine were plotted semilogarithmically and the slope of the curve (elimination rate constant or $\mathrm{K}_{\mathrm{el}}$ ) was calculated with the use of log-linear least-square regression analysis. Apparent volume 
of distribution $\left(\mathrm{AV}_{\mathrm{d}}\right)$ was calculated as dose over the plasma concentration extrapolated to time zero $\left(C_{\mathrm{p}}^{o}\right)$. Plasma half-life was derived from $0.693 / \mathrm{K}_{\mathrm{el}}$ and the clearance rate as the product of $\mathrm{K}_{\mathrm{el}}$ and $A V_{d}$. In the 2 infants who received caffeine orally, analysis assumed complete bioavailability of the drug.

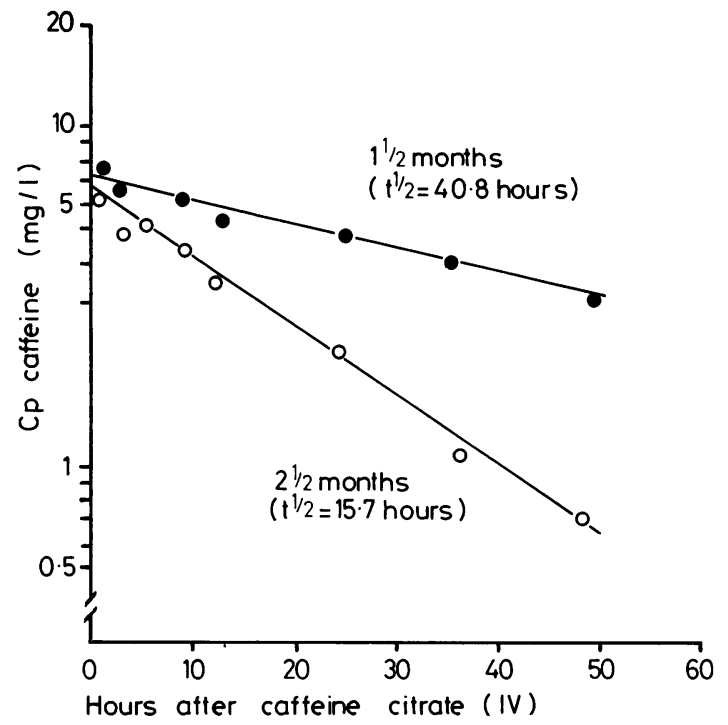

Figure Plasma disappearance curve of intravenously administered caffeine in the same infant at ages $1 \frac{1}{2}$ and $2 \frac{1}{2}$ months. Caffeine citrate, $10 \mathrm{mg} / \mathrm{kg}$ and $5 \mathrm{mg} / \mathrm{kg}$ of active caffeine base, were infused at ages $1 \frac{1}{2}$ and $2 \frac{1}{2}$ months, respectively. Plasma disappearance curve of

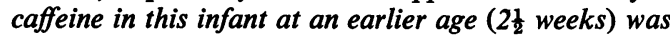
similar to the value obtained at age $1 \frac{1}{2}$ months $\left(t \frac{1}{2}-\right.$ $40 \cdot 8$ hours).

\section{Results}

The Figure shows the sequential changes in the plasma disappearance curve of caffeine in a young infant with increasing postnatal age. The Table shows the pharmacokinetic profile of caffeine as a function of age. Comparative data for the newborn and adults from the same laboratory were included. There was little change in the mean $A_{d}$ over the age

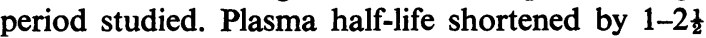
months of age and attained adult t $\frac{1}{2}$ by between 4 and 6 months. Plasma clearance of caffeine progressively increased and achieved comparable adult capacity by 3 to $4 \frac{1}{2}$ months and exceeded adult capacity by 5 to 6 months of age. Change in clearance was mainly a function of an increased elimination rate constant. There was a wide variability in the elimination rate and clearance of caffeine in the newborn and young infant. This wide variability was also observed in adults (Table).

\section{Discussion}

The observation that drugs are eliminated more slowly by neonates than by adults is no longer surprising but the magnitude and duration of the deficit in the case of caffeine exceeds expectations based on the behaviour of other drugs-such as theophylline (Aranda et al,. 1976), phenytoin (Loughnan et al., 1977; Painter et al., 1978), and phenobarbitone (Jalling, 1975; Painter et al., 1978). Both phenytoin and phenobarbitone exhibit 2-to 6-fold prolongation in the plasma half-life relative to the adult (Neims et al., 1976) and the adult level of elimination is achieved within the first month of postnatal life (Neims et al., 1976). In contrast, the plasma half-life

Table Developmental changes in the pharmacokinetic disposition of caffeine in young infants*

\begin{tabular}{|c|c|c|c|c|}
\hline Age group & $A V_{d}(1 / k g)$ & $t \frac{1}{2}(h)$ & $K_{e l}(h-1)$ & Clearance $(\mathrm{ml} / \mathrm{kg}$ per $h)$ \\
\hline $\begin{array}{l}\text { Premature neonates }(n=12) \\
3-32 \text { days }\end{array}$ & $\begin{array}{l}0.916 \\
(0.475-1 \cdot 280)\end{array}$ & $\begin{array}{l}102 \cdot 9 \\
(40 \cdot 8-231)\end{array}$ & $\begin{array}{l}0.009 \\
(0.003-0.017)\end{array}$ & $\begin{array}{l}8 \cdot 9 \\
(2 \cdot 5-16 \cdot 8)\end{array}$ \\
\hline $\begin{array}{l}\text { Term neonates }(n=15) \\
0-4 \text { days }\end{array}$ & - & $\begin{array}{l}80 \cdot 0 \dagger \\
(26)\end{array}$ & - & - \\
\hline \multicolumn{5}{|l|}{$\begin{array}{l}\text { Present report } \\
\text { Young infants }(n=7)\end{array}$} \\
\hline 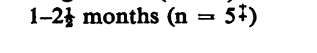 & $\begin{array}{l}0 \cdot 878 \\
(0 \cdot 58-1 \cdot 72)\end{array}$ & $\begin{array}{l}26 \cdot 3 \\
(7 \cdot 5-40 \cdot 8)\end{array}$ & $\begin{array}{l}0.039 \\
(0.017-0.093)\end{array}$ & $\begin{array}{l}31 \cdot 5 \\
(16 \cdot 2-53 \cdot 9)\end{array}$ \\
\hline $3-4 \frac{1}{2}$ months $(n=3 \S)$ & $\begin{array}{l}0.813 \\
(0.44-1.41)\end{array}$ & $\begin{array}{l}14 \cdot 2 \\
(3 \cdot 6-28 \cdot 9)\end{array}$ & $\begin{array}{l}0.094 \\
(0.024-0.191)\end{array}$ & $\begin{array}{l}104 \cdot 6 \\
(14 \cdot 2-269 \cdot 3)\end{array}$ \\
\hline $5-6$ months $(n=2 \approx)$ & $\begin{array}{l}1 \cdot 120 \\
(0 \cdot 70-1 \cdot 54)\end{array}$ & $\begin{array}{l}2 \cdot 6 \\
(2 \cdot 1-3 \cdot 1)\end{array}$ & $\begin{array}{l}0.276 \\
(.224-0.329)\end{array}$ & $\begin{array}{l}331 \cdot 7 \\
(156 \cdot 8-506 \cdot 7)\end{array}$ \\
\hline \multirow{2}{*}{$\begin{array}{l}\text { Adults } \curvearrowleft \\
\quad \text { Nonsmokers }\end{array}$} & & & & \\
\hline & $\begin{array}{l}0 \cdot 610 \\
(0 \cdot 12-1 \cdot 02)\end{array}$ & $\begin{array}{l}6 \cdot 0 \\
(3 \cdot 0-9 \cdot 4)\end{array}$ & $\begin{array}{l}0.130 \\
(0.074-0.234)\end{array}$ & $\begin{array}{l}94 \cdot 0 \\
(21 \cdot 0-270 \cdot 0)\end{array}$ \\
\hline Smokers & $\begin{array}{l}0.720 \\
(0.12-0.97)\end{array}$ & $\begin{array}{l}3 \cdot 5 \\
(1 \cdot 5-5 \cdot 9)\end{array}$ & $\begin{array}{l}0.230 \\
(0 \cdot 117-0.461)\end{array}$ & $\begin{array}{l}155 \cdot 0 \\
(69 \cdot 0-268 \cdot 0)\end{array}$ \\
\hline
\end{tabular}

* Comparative data obtained from the same laboratory. Values expressed as mean and range.

†Disappearance curve drawn from 2 points: cord blood sample and a 4-day sample (Parsons et al., 1976), ¥includes 3 sequential studies in one

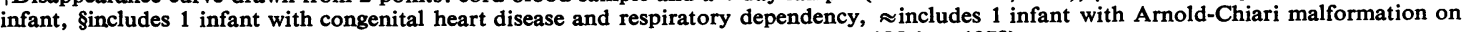
phenobarbitone and phenytoin, $\varnothing$ smoking accelerates caffeine elimination (Parsons and Neims, 1978). 
of caffeine represents a 17 -fold prolongation relative to the adult, and the adult capacity to eliminate the drug is achieved much later (3-4 $\frac{1}{2}$ months).

One biochemical basis for this finding could be a decreased oxidative metabolism of caffeine by the newborn and young infant (Aranda et al., 1974; Neims et al., 1976). In adults, less than $2 \%$ of a caffeine dose is eliminated unchanged in urine, the remainder being metabolised in the liver to a series of partially demethylated xanthines and methyl uric acids (Cornish and Christman, 1957; Burg, 1975). In contrast, Horning et al. (1975) found that transplacentally acquired caffeine was largely excreted unchanged in comparison with its demethylated metabolites in the urine of 1- to 3-day-old neonates. This was confirmed by Aldridge et al. (1979), who found that unchanged caffeine comprised more than $85 \%$ of the methylated xanthines and methyl uric acids in the urine of infants less than one month of age. These observations indicate a distinct neonatal deficiency in the capacity to metabolise caffeine, and this deficit persists for many weeks since caffeine remained the predominant component in the urine for at least $\mathbf{3}$ months postnatally. It is intriguing to relate that the adult plasma clearance rate is achieved

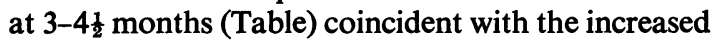
capability to produce demethylated metabolites (Aldridge et al., 1979).

The oxidative metabolism of drugs via the cytochrome $\mathrm{P}-450$ mono-oxygenase system is deficient in the human neonate (Aranda et al., 1974; Neims et al., 1976). The relative deficiency with regard to methylxanthine metabolism is greater than seen with other drugs. One subcellular explanation for this difference relates to the existence of multiple forms of cytochrome P-450, each with distinctive substrate specificity and maturational sequence (Thomas et al., 1976; Manchester and Neims, 1977). Caffeine is a good substrate for those form(s) of cytochrome P-450 preferentially induced by polycyclic aromatic hydrocarbons in rats (Welch et al., 1977) and in man. This form of cytochrome P-450 with specific activity for caffeine is probably deficient in the fetus and newborn as suggested by negligible aryl hydrocarbon hydroxylase activity (about $2 \%$ of adult value) in the human fetal liver compared with other oxidative enzymes of the mono-oxygenase complex that preferentially metabolise drugs like phenytoin or phenobarbitone $(25-50 \%$ of adult value) (Pelkonen et al., 1973; Neims et al., 1976).

Phenobarbitone and phenytoin, both known enzyme inducers, were used in one infant (Table) with the highest clearance rate. The possibility that the elimination of caffeine in this infant could have been induced by these drugs exists, but available data suggest that phenobarbitone and phenytoin have little effect on methylxanthine disposition (Greene et al., 1977; Piafsky et al., 1977; Ogilvie, 1978).

The lack of correlation between indices of maturity (gestational age, postnatal age, birthweight) and the kinetic variables $\left(\mathrm{AV}_{\mathrm{d}}, \mathrm{t} \frac{1}{2}, \mathrm{~K}_{\mathrm{el}}\right.$, and clearance) during the first 4 weeks of life (Aranda et al., 1979) suggest that elimination does not change during the first few weeks of postnatal life. Shortening of the plasma $t \frac{1}{2}$ starts to occur after the neonatal period and appears to reach adult $t \frac{1}{2}$ by $5-6$ months, perhaps to be exceeded thereafter. A much greater clearance rate of drugs in infants after one year of age has been documented with other drugs-such as digoxin (Morselli et al., 1975; Wettrell, 1977; Wettrell and Anderson, 1977) and theophylline (Loughnan et al., 1976; Ogilvie, 1978). Caffeine appears to behave similarly, based on the observations of a 3-fold increase in the mean caffeine clearance rate in the 5- to 6-month-old infant (Table). The fundamental basis for this accelerated clearance rate in older infants compared with adults remains unknown. Similarly, the duration of this accelerated elimination is also not known. The oldest infant studied here was 6 months and ethical consideration has precluded extension of this study to older normal healthy infants.

In summary, our data show that caffeine elimination, unlike that of other drugs, is exceedingly slow in the neonate with tardy maturation to the adult level.

We thank Dr Allen H. Neims in whose laboratory some of the caffeine assays were done, and Rena Jain for technical assistance. This work was supported by grants from the Medical Research Councils of Quebec and Canada.

\section{References}

Aldridge, A., Aranda, J. V., and Neims, A. H. (1979). Caffeine metabolism in the newborn. Clinical Pharmacology and Therapeutics, 25, 447-453.

Aranda, J. V., MacLeod, S. M., Renton, K. W., and Eade, N. R. (1974). Hepatic microsomal drug oxidation and electron transport in newborn infants. Journal of Pediatrics, 85, 534-542.

Aranda, J. V., Sitar, D. S., Parsons, W., Loughnan, P. M., and Neims, A. H. (1976). Pharmacokinetic aspects of theophylline in premature newborns. New England Journal of Medicine, 295, 413-416.

Aranda, J. V., Gorman, W., Bergsteinsson, H., and Gunn, T. (1977a). Efficacy of caffeine in treatment of apnea in the low-birth-weight infant. Journal of Pediatrics, 90, 467-472.

Aranda, J. V., Gorman, W., Outerbridge, E. W., and Neims, A. H. (1977b). Pharmacokinetic disposition of caffeine in premature neonates with apnea (abstract). Pediatric Research, 11, 414.

Aranda, J. V., Cook, C. E., Gorman, W., Collinge, J. M., Loughnan, P. M., Outerbridge, E. W., Aldridge, A., and Neims, A. H. (1979). Pharmacokinetic profile of caffeine in the premature newborn with apnea. Journal of Pediatrics, 94, 663-668. 
Bory, C., Baltassat, P., Porthault, M., Bethenod, M., Frederich, A., and Aranda, J. V. (1979). Metabolism of theophylline to caffeine in the premature neonate. Journal of Pediatrics, 94, 988-993.

Burg, A. W. (1975). Physiological disposition of caffeine. Drug Metabolism Reviews, 4, 199-228.

Cook, C. E., Tallent, C. R., Emerson, E. W., Myers, M. W., Kepler, J. A., Taylor, G. F., and Christensen, H. D. (1976). Caffeine in plasma and saliva by a radio-immunoassay procedure. Journal of Pharmacology and Experimental Therapeutics, 199, 679-686.

Cornish, H. H., and Christman, A. A. (1957). A study of the metabolism of theobromine, theophylline, and caffeine in man. Journal of Biological Chemistry, 228, 315-323.

Greene, J., Danish, M., Radui, M., Lecks, H., and Yaffe, S. (1977). The effect of phenobarbital upon theophylline elimination kinetics in asthmatic children (abstract). Annals of Allergy, 39, 69.

Horning, M. (1977). Breast milk transfer of caffeine. Proceedings of FASEB Hearing on Caffeine, pp. 28-36. ACE Reporters: Washington DC.

Horning, M. G., Butler, C. M., Nowlin, J., and Hill, R. M. (1975). Drug metabolism in the human neonate. Life Sciences, 16, 651-671.

Jalling, B. (1975). Plasma concentrations of phenobarbital in the treatment of seizures in newborns. Acta paediatrica Scandinavica, 64, 514-524.

Loughnan, P. M., Sitar, D. S., Ogilvie, R. I., Eisen, A., Fox, Z., and Neims, A. H. (1976). Pharmacokinetic analysis of the disposition of intravenous theophylline in young children. Journal of Pediatrics, 88, 874-879.

Loughnan, P. M., Greenwald, A., Purton, W. W., Aranda, J. V., Watters, G., and Neims, A. H. (1977). Pharmacokinetic observations of phenytoin disposition in the newborn and young infant. Archives of Disease in Childhood, 52, 302-309.

Manchester, D. K., and Neims, A. H. (1977). Multiplicity of cytochrome $\mathbf{P}-450$ during development (abstract). Pediatric Research, 11, 418.

Morselli, P. L., Assael, B. M., Gorman, R., Mandelli, M., Marini, A., Reali, E., Visconti, U., and Sereni, F. (1975). Digoxin pharmacokinetics during human development. In Basic Therapeutic Aspects of Perinatal Pharmacology, pp. 377-392. Edited by P. L. Morselli, S. Garattini, and F. Sereni. Raven Press: New York.
Neims, A. H., Warner, M., Loughnan, P. M., and Aranda, J. V. (1976). Developmental aspects of cytochrome P-450 mono-oxygenase system. Annual Review of Pharmacology and Toxicology, 16, 427-446.

Ogilvie, R. I. (1978). Clinical pharmacokinetics of theophylline. Clinical Pharmacokinetics, 3, 267-293.

Painter, M. J., Pippinger, C., MacDonald, H., and Pitlick, W. (1978). Phenobarbital and diphenylhydantoin levels in neonates with seizures. Journal of Pediatrics, 92, 315-319.

Parsons, W., Aranda, J. V., and Neims, A. H. (1976). Elimination of caffeine in the newborn (abstract). Pediatric Research, 10, 333.

Parsons, W. D., and Neims, A. H. (1978). Effect of smoking on caffeine clearance. Clinical Pharmacology and Therapeutics, 24, 40-45.

Pelkonen, O., Katiala, E. H., Larmi, T. K. I., and Karlu, N. T. (1973). Comparison of activities of drug metabolizing enzymes in human fetal and adult livers. Clinical Pharmacology and Therapeutics, 14, 840-846.

Piafsky, K. M., Sitar, D. S., and Ogilvie, R. I. (1977). Effect of phenobarbital on the disposition of intravenous theophylline. Clinical Pharmacology and Therapeutics, 22, 336-339.

Thomas, P. E., Lu, A. Y. H., Ryan, D., West, S. B., Kawalek, J., and Levin, W. (1976). Multiple forms of rat liver cytochrome P-450. Immunochemical evidence with antibody against cytochrome P-448. Journal of Biological Chemistry, 251, 1385-1391.

Welch, R. M., Hsu, S. Y., and De Angelis, R. L. (1977) Effect of Arochlor 1254, phenobarbital, and polycyclic aromatic hydrocarbons in the plasma clearance of caffeine in the rat. Clinical Pharmacology and Therapeutics, 22, 791-798.

Wettrell, G. (1977). Distribution and elimination of digoxin in infants. European Journal of Clinical Pharmacology, 11, 329-335.

Wettrell, G., and Anderson, K. E. (1977). Clinical pharmacokinetics of digoxin in infants. Clinical Pharmacokinetics, 2, 17-31.

Correspondence to Dr J. V. Aranda, McGill University-Montreal Children's Hospital, 2300 Tupper Avenue, Montreal, Quebec H3H 1P3, Canada.

Received 20 March 1979 